\title{
THE STRENGTHENING OF PANCASILA AS DARUL 'AHDI WA AL-SYAHADAH AT THE MUHAMMADIYAH UNIVERSITY
}

\author{
Anita Pujiastutik ${ }^{1} \&$ Ahmad Nur Fuad ${ }^{2}$ \\ Department of Islamic Education, Universitas Muhammadiyah Sidoarjo \\ Department of Islamic Education, Universitas Islam Negeri Sunan Ampel Surabaya
}

DOI: 10.29322/IJSRP.10.02.2020.p9820

http://dx.doi.org/10.29322/IJSRP.10.02.2020.p9820

\begin{abstract}
Muhammadiyah is committed to making the state of Pancasila as Darul 'Ahdi wa al-Syahadah or a country of witness and proving itself in filling and building a meaningful national life towards progress in all fields of life. Universitas Muhammadiyah Sidoarjo students as educated people in Muhammadiyah institutions should understand the nationalism movement in the Muhammadiyah movement. This research is to find out the knowledge and understanding of students about the commitment of the Muhammadiyah Pancasila as Darul 'Ahdi wa al-Syahadah in the hope of anticipating the proliferation of radical student movements and at the same time to follow up on the results of the 47th Muhammadiyah Conference in Makassar that produced the concept of "Pancasila State as Darul "Ahdi wa al-Syahadah ". The methodology in this study uses a descriptive qualitative approach by looking at visible phenomena. Primary data sources obtained by researchers through a questionnaire or questionnaire with a purposive sampling technique. The results showed that the knowledge of students about Pancasila was quite good. The student's understanding of the Pancasila Muhammadiyah's commitment as Darul 'Ahdi wa al-Syahadah showed that the results of the conference had not been fully socialized either individually or at a more general level. So it is necessary to carry out the socialization of Pancasila as Darul 'Ahdi wa al-Syahadah through seminars or discussion forums among Muhammadiyah students in order to have a deep understanding of nationalism.
\end{abstract}

Index Terms- Darul 'Ahdi wa al-Syahadah, Strengthening, Pancasila

\section{INTRODUCTION}

$\mathrm{T}_{\mathrm{l}}$ The discussion of whether Islam really compels Muslims to form a nation formally called Islamic State is very interesting to study. In the national life, the Muhammadiyah and the Muslims as a majority have a great and important responsibility to make Indonesia the Baldatun Thayyibatun Wa Rabbun Ghafur, a good nation and in God's forgiveness (QS. Saba: 15). In that country the people believed and feared so that Allah blessed them (QS Al.A'raf: 96) they built the country well and did no harm (QS Al Baqarah: 11; Ar Ruum: 41; Al Qashash: 77). Thus the Muhammadiyah is committed to continuing to strive to project Indonesia into a developed, just, prosperous, dignified, and sovereign State in the protection of Allah Almighty.

The concept of the Pancasila State as Darul 'Ahdi wa al-Syahadah is based on official thoughts which have been the guideline and reference of organizations such as the Matan Keyakinan dan Cita-cita Hidup Muhammadiyah (MKCH), Khittah Muhammadiyah, Building the Vision and Character of the Nation, Developing Indonesia, and the results of Tanwir Muhammadiyah in Bandung 2012 and Tanwir Samarinda 2014. Muhammadiyah citizens in particular and Muslims in general as the majority power are expected to be able to fill and develop the Pancasila State namely Negara Kesatuan Republik Indonesia (NKRI) based on Pancasila and UUD 1945 as a country and nation that is developed, just, prosperous, dignified, and sovereign in line with the ideals of Baldatun Thayyibatun Wa Rabbun Ghafur.

In this age of information disclosure, our country is confronted with various other extreme ideologies. Call it liberalism and communism and even extreme religious sects. Student intellectuality can be actualized in the world of campus. Referring to the words of the figure Masyumi M. Natsir, that the campus is the third stronghold of Muslims after the mosque and boarding school. So it should be, students can be the pioneers of the revolution in Indonesia.

Education can change a person from his status as a citizen because they are forced to become citizens with awareness [1]. Students are able to provide a change in society and even the country. Students are elements of society that are able to make the flow of change in civilization. Aristotle states if the world of education is ignored in the formation of political culture, then it cannot guarantee the survival of a country, even the country is in serious [2]. 
As an agent of change, students are the spearhead of the nation's future development, having a deep and strategic contribution relationship through their ideas and work. Their identity and ideology as intellectuals will contribute to the progress of the nation. Since the struggle to the present history, it is noted that youth form the basis of the state, build it and act as a carrier of global change and its existence, which is critical, active and innovative and multi-disciplinary in various fields of Indonesian national life.

The formation of Indonesia now begins with the movement of the younger generation driven by students which is a milestone. After the Reformation period, many questions and concerns that occurred in the minds of the people against the Student movement activism. Lately, Indonesia has been characterized by the phenomenon of radicalism among students. In fact, the latest developments inform that religious-based campuses are also not spared from recruiting radical movements.

Based on the background given above, the need for this study reinforces previous research written by Baehaqi [3], so that the following issues can be formulated (1) How knowledge level and understanding of Muhammadiyah's commitment to Pancasila as Darul 'Ahdi wa al-Syahadah among students ?, and (2) How is the solution to strengthening the understanding of Muhammadiyah's commitment to Pancasila as Darul 'Ahdi wa al-Syahadah among students?

\section{RESEARCH METHOD}

The methodology in this study using a qualitative approach with descriptive methods. The qualitative descriptive format aims to describe, summarize the various conditions, or various phenomena regarding the understanding of Pancasila as Darul 'Ahdi wa alSyahadah in the Universitas Muhammadiyah Sidoarjo.

The determination of the informants was done by purposive sampling. Namely the sample chosen deliberately with the consideration that the selected informant is considered capable of providing the information needed. Data about the understanding of Pancasila as Darul 'Ahdi wa al-Syahadah students were obtained through a questionnaire or questionnaire to students as well as observations in the Universitas Muhammadiyah Sidoarjo. Original, credible and relevant data with the focus of this research are then interpreted and analyzed into a study.

\section{RESULTS AND DISCUSSION}

\section{A. Student Understanding of the Thought as Darul 'Ahdi wa al-Syahadah}

Student Knowledge of the Universitas Muhammadiyah Sidoarjo on Muhammadiyah Pancasila's commitment as Darul 'Ahdi wa alSyahadah is a representation of what the individual believes, contains the individual's understanding and knowledge of what is happening or what is true of the object being perceived. Cognitive aspects of this study are the students 'knowledge and knowledge of Pancasila as Darul' Ahdi wa al-Syahadah which is a Muhammadiyah commitment to the nation and nation.

The results obtained from the interviews of several students across the faculty at Muhammadiyah Sidoarjo University (FAI, FBHIS, FPIP), show that almost all students do not know the meaning of Darul 'Ahdi wa al-Syahadah in both language and terms. Only a few students from the Faculty of Islamic Religions can give the linguistic explanation of Darul 'Ahdi wa al-Syahadah, a state of agreement and testimony. To be more fully understood, the State of Pancasila is the result of a national consensus (dar al-'ahdi) and a place of proof or testimony (of the al syahadah) to be a safe and peaceful state (from al salam) towards a prosperous, just, prosperous, dignified, and ruling in the shadow of the Almighty Allah.

Students understand more about Pancasila as a substance. Pancasila as elements that come from themselves [4]. The elements of Pancasila have not fully become a reality. The meaning is that Pancasila does not always exist in him which is actualized in daily life. This is also evident from the results of observations, which indicate that their attitudes are not yet dominant towards the implementation of Pancasila values. Whereas in order to realize consistency about Muhammadiyah's national commitment about Pancasila as Darul 'Ahdi wa al-Syahadah, students must first show an attitude that reflects the values of Pancasila.

Kunto Wibisono in Kurniawan [5] mentions three dominant elements in ideology, namely: 1) the existence of beliefs, 2) myths, and 3) loyalty. Further stated the role of ideology in social life can be seen from three dimensions, namely: 1) the ideal dimension; 2) the dimension of reality, and 3) the dimension of flexibility. Kaelan [6] states, "Pancasila as an ideology is not rigid and closed, but is reformative, dynamic and open." The actual thing and always able to adjust to the development of time, technology and the development of a society or can be said that the ideology of Pancasila is an open ideology not a closed ideology.

Muhammadiyah strongly accepts the ideology of Pancasila by implementing it in all fields. This statement of Muhammadiyah has been known by most Muhammadiyah students, but the form of its implementation has not been understood in detail. This has intrigued researchers to conduct socialization about Pancasila as Darul 'Ahdi wa al-Syahadah.

\section{B. Socialization of Pancasila as Darul 'Ahdi wa al-Syahadah}

Political socialization in educational institutions can take place through the curriculum. Zais [7] considers that the curriculum is "........ a course of subject matters to be mastered", while Caswell and Campbell declare the curriculum "......... to be composed of all the experiences children have under the guidance of teacher " [8]. But the learning experience can be done in the classroom or outside the classroom.

Pancasila Socialization as Darul 'Ahdi wa al-Syahadah as a solution to provide knowledge and understanding to students. The material begins with synchronizing the values in the Pancasila precepts (See Figure 1) with verses from the Quran [9]. 


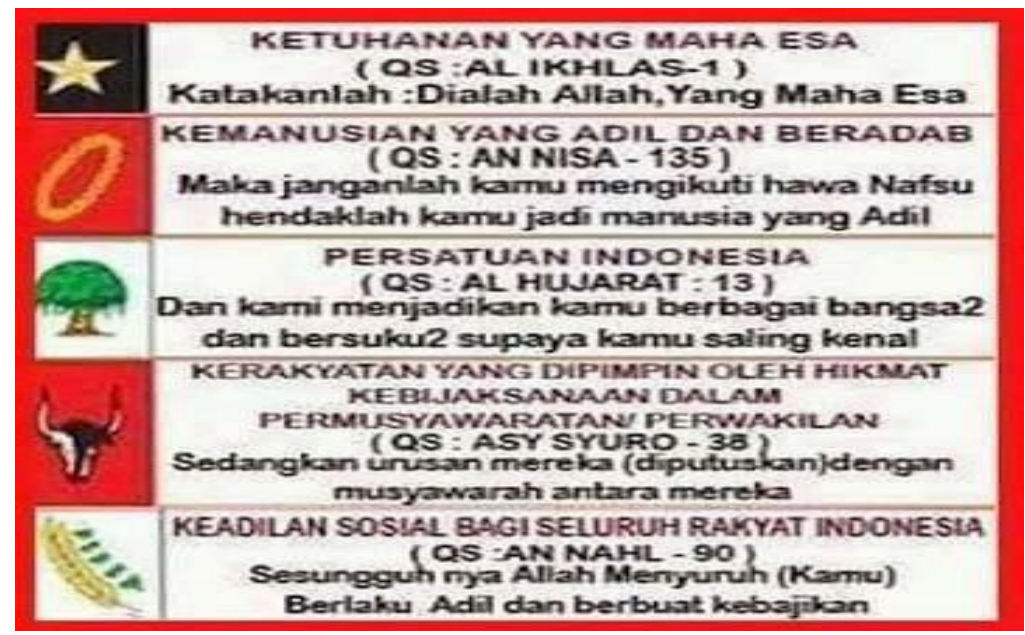

Figure 1. Items of Pancasila Values

In English Figure 1 explains that the 1st Precept: The Almighty God (QS: Al Ikhlas-1). Say: He is Allah, the One. The 2nd Precepts: Just and civilized humanity (QS: An Nisa-135). Then do not follow the passions you should become just human. The 3rd Precept of Indonesian Unity (QS: Al Hujarat: 13). And we made you various nations and tribes so that you knew one another. The 4th People's Precept is led by wisdom in the deliberative deliberations (QS: Asy Syuro-38). While their affairs (decided) with deliberation between them. The 5th Precept Social justice for all Indonesian people (QS: An Nahl-90). Verily Allah tells (You) to be just and do good.

Muhammadiyah as an Islamic Movement is fully aware that the State of Indonesia is a place to carry out missionary and tajdid missions for the realization of the true Islamic community. Muhammadiyah along with other Muslim and Indonesian components fought in the national revival movement towards independence and played an active role in establishing the Republic of Indonesia which was proclaimed on August 17, 1945.

The Muhammadiyah nationalist view affirms the commitment of the United State of the Republic of Indonesia based on the Constitution and the Constitution of 1945. This reinforces Baidhawi's determination to carry out further studies of the Pancasila State as Darul 'Ahdi wa al-Syahadah which constitutes the Muhammadiyah national commitment. The Muhammadiyah's nationalist views affirm the commitment of the United Nations of the Republic of Indonesia based on the Constitution and the Constitution of 1945 and are consistent in integrating Islam and Indonesia [10].

The 47th Muhammadiyah Congress on 18-22 Shawwal 1436 Hijriyah coincides August 3-7, 2015 the miladiyah in Makkassar had presented the material "Pancasila State as Darul 'Ahdi wa al-Syahadah" which was based on official thoughts which had been the guideline so far. and referral organizations such as Matan Keyakinan dan Cita-Cita Hidup Muhammadiyah (MKCH) Kepribadian Muhammadiyah, khittah muhammadiyah, and the results of the Muhammadiyah plant in 2012 and Samarinda in 2014.

According to the General Chairperson of Muhammadiyah Central Leadership (2005-2015 period) Din Syamsuddin, the Pancasila state was a consensus or agreement (darul 'ahdi) of all the founding fathers of the nation (the founding fathers). The consensus was clearly of religious dimension so it demanded a commitment to continue to safeguard the Pancasila state with full trust. The State of Pancasila should also be an arena for giving testimony or proof (darusy syahadah). That means, all elements of the nation must compete to be the best with a commitment to realize the ideals of our beloved country.

As the majority group in our beloved country, the commitment of Muslims towards Pancasila cannot be doubted. When some elements of the nation objected to the formulation of the Pancasila contained in the Jakarta Charter, Ki Bagoes Hadikoesoemo who was then a member of the Indonesian Independence Preparatory Committee (PPKI) and chairman Hoof Bestuur Muhammadiyah appeared as a hero. In the PPKI session in August 1945, Ki Bagoes was willing to change the formulation of the first precepts of Pancasila into a Godhead.

In fact, previously PPKI members had agreed to the Jakarta Charter statement in which there were the first precepts of the formulation of the Pancasila which read God with the obligation to carry out Islamic law for its adherents. However, because there were objections to the threat of leaving the country of Indonesia if the first precepts were not changed, Islamic figures were tolerant. These historical facts show that Islamic leaders have made extraordinary sacrifices to maintain the country's unity. The willingness of Islamic leaders to erase the seven words in the Jakarta Charter is not without challenges. Some Islamic leaders at that time seemed disappointed with the change in the formulation of the first precepts of Pancasila.

Historical perspective is important to show people that the Pancasila and Negara Kesatuan Republik Indonesia (NKRI) are final. Thus, the debate over the basis of the state and the form of the state should end. However, the impact of global political dynamics turned out to be extraordinary in the views of some Islamic political movement activists. Relentlessly the group with transnational ideology continues to move. They inflame transnational political views through the establishment of the caliphate.

The idea is a reference and action for all members of the Muhammadiyah in national life and in their context contextually based on the progressive Islamic view that has always been the perspective of the Muslim muhammadiyah. Muhammadiyah as an Islamic 
movement is fully aware that Indonesia is a place of mission and tajdid mission for the realization of the true Muslim community. Muhammadiyah along with components of Islam and the Indonesian people fought in the national revival movement towards independence and played an active role in establishing the Republic of Indonesia. therefore as embodied in the fifth article of the Muhammadiyah (MKCH) faith and aspirations of 1969, as a gratitude and a religious and national responsibility "Muhammadiyah invites all layers of Indonesian people who have received the gift of Allah in the form of their homeland. , the independence of the nation and the Republic of Indonesia based on the Constitution and the constitution of 1945, to work together to make a just prosperous nation favored by the god subhanahu wata ala: "baldatun thayyibatun wa rabbun ghafur" [11].

The Pancasila State's view as Darul 'Ahdi wa al-Syahadah, departed from three main backgrounds. First, there are groups or some elements of society, especially Muslim communities who still question the relationship between Islam and the state, and question the Indonesian state based on Pancasila. Second, there is the reality that as a nation ideologically it has not been formulated very explicitly and made an academic explanation about the Pancasila state. Third, there is a reality where the Islamic community is considered as a threat to the Pancasila state [12]. From this reality, Muhammadiyah needs to make a statement that as an organization Muhammadiyah accepts Pancasila as an ideal form, both philosophical and ideological in nature. Even also constitutionally in terms of nation and state [13].

After the implementation of socialization, students gained knowledge and understanding of Pancasila as Darul 'Ahdi wa alSyahadah. The results of the final interview with several students across the faculty (FAI, FBHIS, FPIP) indicate that there is an increase in understanding of Muhammadiyah's national commitment. Almost all respondents understood Darul 'Ahdi wa alSyahadah's meaning in both language and terms. Students better understand the logical consequences of the Muhammadiyah agreement to make Pancasila as a philosophy of the nation and then please all Pancasila color the entire field of Muhammadiyah.

\section{CONCLUSION}

Based on the research done, the following conclusions can be drawn that almost all students do not know the meaning of Darul 'Ahdi wa al-Syahadah either in language or in terms. Only a few students from the Faculty of Islamic Religions can give the language meaning in the meaning of Darul 'Ahdi wa al-Syahadah, a state of agreement and testimony. Socialization of Pancasila as Darul 'Ahdi wa al-Syahadah as a solution to provide knowledge and understanding to the Students. From here, students gain knowledge and understanding of Pancasila as Darul 'Ahdi wa al-Syahadah. The results of the final interview indicate that there is an increased understanding of Muhammadiyah's national commitment. Almost all respondents understood Darul 'Ahdi wa al-Syahadah's meaning in both language and terms. Students better understand the logical consequences of the Muhammadiyah agreement to make Pancasila as a philosophy of the nation and then please all Pancasila color the entire field of Muhammadiyah.

\section{ACKNOWLEDGMENT}

First of all, thanks to Allah for his mercy and guidance in giving me full strength to complete this article. A lot of thanks to my promotor, Prof. Acmad Jainuri, Ph.D. and Dr. Achmad Nur Fuad for all of his support and guidance in helping me to finish my research. Thanks to PP Muhammadiyah for providing motivation in the form of funding this research for expanding the mission of Muhammadiyah. Special appreciation is given to editors who have reviewed, who have provided suggestions and criticisms for improving this article. Finally, I am indebted to my parents, my lovely husband Sunarto, my precious son Fahmi, Rafsa, Reza and my little daughter Meeva for their continuous support and encouragement.

\section{REFERENCES}

U. A. M. Ruslan, Pendidikan Politik Ikhwanul Muslimin. Solo: Intermedia, 2000.

Aristoteles, "Politiea," in Al-Siyâsah, A. L. Sayyid, Ed. Kairo: Dâr al-Qoumiyah li al-Thibâ'ah wa al-Nasyr.

D. B. Arif and S. S. Aulia, "Studi Tentang Negara Pancasila Sebagai Darul Ahdi Wa Syahadah untuk penguatan materi pembelajaran pendidikan kewarganegaraan di Universitas Universitas Ahmad Dahlan," J. Civ., vol. 14, no. 2, 2017.

S. Syarbaini, Membangun karakter dan Kepribadian Melalui Pendidikan Kewarganegaraan. Yogyakarta: Graha Ilmu, 2006.

F. Kurniawan, "Ideologi Besar dan Pancasila," The Rangkuman Blogspot, 2012. [Online]. Available: therangkuman.blogspot.com.

M. S. Kaelan, Pendidikan Kewarganegaraan untuk Perguruan Tinggi. Yogyakarta: Paradigma, 2010.

R. S. Zais, Curriculum Principles and Foundations. New York: Harper\& Row Publisher, 1976.

N. S. Sukmadinata, Pengembangan Kurikulum Teori dan Praktek. Bandung: Remaja Rosdakarya, 2007.

Z. Baidhawy, "Negara Pancasila sebagai negara syariah," MA'ARIF, vol. 10, no. 1, 2015.

H. Nashir, Kuliah kemuhammadiyahan. Yogyakarta: LPSI UAD dan Suara Muhammadiyah, 2016.

P. Muhammadiyah, "Negara Pancasila Sebagai Darul Ahdi Wa Syahadah,” in Muktamar Muhammadiyah ke 47 Makassar, 2015.

A. Mu'ti, "Editorial: Dialog," Suara Muhammadiyah, 2015. [Online]. Available: http://www.suaramuhammadiyah.id/2 015/12/28/masih-perlu-road-mapmengisi-negara-pancasila.

Biyanto, "Pancasila Sebagai Darul “Ahdi wasy Syahadah,” Jawa Pos, Surabaya, 19-May-2017. 


\section{AUTHORS}

First Author - Anita Puji Astutik, Islamic Study, Faculty of Islamic Study, Universitas Muhammadiyah Sidoarjo, email: anitapujiastutik@umsida.ac.id. Correspondence Author.

Second Author - Ahmad Nur Fuad, Islamic History, Faculty of Humaniora, Postgraduate, Universitas Islam Negeri Sunan Ampel Surabaya, email: ahmadnurfuad@yahoo.com. 